\title{
Apontamentos sobre a construção mítica e publicitária das atletas da seleção brasileira em peças veiculadas durante a Copa do Mundo de futebol feminino 2019
}

\author{
Fernanda Weyh ${ }^{1}$ \\ Maurício Barth ${ }^{2}$ \\ Gustavo Roese Sanfelice ${ }^{3}$
}

\begin{abstract}
Resumo
Este trabalho tem como objetivo analisar a construção mítica e publicitária das atletas da Seleção Brasileira em peças veiculadas durante a Copa do Mundo de Futebol Feminino 2019. Para tanto, foram selecionados, a fim de cumprir o objetivo proposto, os comerciais: (1) Marta \#ElaÉNúmero 1, (2) Andressa Alves' Story e (3) Copa do Mundo Feminina da FIFA, analisados através da Retórica da Imagem de Barthes (1990). Ao fim do estudo, constatou-se que as peças selecionadas potencializaram a criação e recriação de atletasmito, despertando a atenção nos comerciais publicitários estudados através de pontos como talento, superação e habilidade e, até mesmo, à "alegria” das jogadoras - remetendo à brasilidade. Concluiu-se, ainda, que o atleta-mito personifica, portanto, a figura com a qual muitas pessoas se identificam, sendo considerado um modelo exemplar para a humanidade, com seus desafios, dificuldades e sofrimentos, com suas vitórias e derrotas; enfim, com a luta pela sua história.
\end{abstract}

Palavras-chave: Publicidade. Mito. Futebol.

\begin{abstract}
This work aims to analyze how the mythical construction and advertising of the athletes of the Brazilian team took place in pieces broadcast during the Women's Soccer World Cup 2019. For this purpose, the commercials were selected, in order to fulfill the proposed objective: (1) Marta \#ElaÉNúmero 1, (2) Andressa Alves' Story and (3) FIFA Women's World Cup, analyzed through Image Rhetoric of Barthes (1990). At the end of the study, it was found that the selected pieces potentiated the creation and recreation of athletemyths, attracting attention in the commercials studied through points such as talent,

\footnotetext{
'Bacharela em Publicidade e Propaganda pela Universidade Feevale. fernanda weyh@gmail.com

2 Doutorando em Diversidade Cultural. Professor no Curso de Publicidade e Propaganda da Universidade Feevale. mauricio@feevale.br

3 Doutor em Comunicação. Coordenador do Programa de Pós-Graduação em Diversidade Cultural e Inclusão Social da Universidade Feevale. sanfelice@feevale.br
} 


\section{VOZES \\ DIÁLORO}

Itajaí, V. 20, n.01, jan-jun 2021

overcoming and skill with the ball and, even, the "joy" of the players, referring to the brazilianness that the spectator so admires, striking characteristics and, also, fundamental to achieve success in the sport. It was also concluded that the athlete-myth personifies, therefore, the figure with which many people identify, being considered an exemplary model for humanity, with its challenges, difficulties and sufferings, with its victories and defeats; finally, with the fight for its history.

Keywords: Publicity; Myth; Soccer.

\section{Introdução}

Dada a sua importância para os brasileiros, o futebol é responsável por mover a vida de inúmeras pessoas por todo o país, proporcionando, entre muitos outros sentimentos possíveis, sensações inigualáveis de alegria e entusiasmo. Sob esse prisma, o público respira e vive, de forma intensa, essa paixão, especialmente durante o apogeu do megaevento esportivo: a Copa do Mundo, que, em 2019, teve a oitava edição de sua versão feminina disputada durante os meses de junho e julho, na França.

Nesse sentido, durante a Copa do Mundo Feminina de 2019, o futebol foi bastante explorado pela publicidade das empresas com o objetivo de aumentar as vendas e fortalecer suas marcas, possuindo o maior ${ }^{4}$ alcance midiático da história. Antes mesmo do seu início, mais ${ }^{5}$ de 800 mil ingressos já haviam sido vendidos para a Copa de 2019 - e as entradas para abertura, semifinais e final esgotaram em 48 horas. Foram estádios lotados, recorde em vendas de ingressos e milhares de pessoas ao redor do mundo acompanhando o crescimento do futebol feminino. Foi um novo capítulo na história do esporte para as atletas, que fizeram a Copa do Mundo de Futebol Feminino na França ser eternamente lembrada em todos os veículos de comunicação.

Não é de hoje que o futebol, vinculado à publicidade, mostra-se importante para gerar engajamento e atingir resultados cada vez mais produtivos. ${ }^{6}$ Com megaeventos esportivos, a publicidade está cada vez mais próxima do consumidor, e isto é visto em grandes campanhas publicitárias esportivas que cumprem com seus objetivos ao transmitirem toda a ascensão de um esporte ou de um atleta. A paixão por esse esporte é a porta de entrada para empresas potencializarem a exibição de sua marca na mídia esportiva.

\footnotetext{
${ }^{4}$ Disponível em: <https://www.meioemensagem.com.br/home/midia/2019/07/08/futebol-femininorecordes-e-a-sensacao-de-que-nada-sera-como-antes.html >. Acesso em: 09 mar. 2020.

${ }^{5}$ Disponível em: 〈https://www.bbc.com/portuguese/geral-48550090〉. Acesso em: 12 mar. 2020.

${ }^{6}$ No campo científico, o futebol se mostra um objeto explorado por inúmeras(os) áreas, países, universidades, autores e periódicos (BARTH; SANFELICE, 2019).
} 


\section{VOZES $_{\text {\&IÁLORO }}^{\mid}$}

Itajaí, V. 20, n.01, jan-jun 2021

Sendo assim, a publicidade no futebol, muitas vezes, tem como protagonista um atleta esportivo de importância, que, com sua imagem construída pela mídia, se transforma em mito esportivo. Os atletas-mito são personagens criados e sustentados pela mídia, que tem sua narrativa recontada em anúncios publicitários, ressaltando sua carreira de sucesso e habilidades no esporte. Grandes marcas utilizam-se da imagem desses atletas para promover a venda de produtos e movimentar o mercado, tornando, assim, o futebol um negócio vantajoso na publicidade.

Dessa forma, o poder da publicidade ligada a esses atletas vai além de valorizar marcas ou vender produtos; criam-se conexões com o consumidor por se tratarem de atletas-heróis, mitos que têm suas histórias exibidas em campanhas publicitárias. Sob esse contexto, este trabalho tem como objetivo analisar a construção mítica e publicitária das atletas da Seleção Brasileira em peças veiculadas durante a Copa do Mundo de Futebol Feminino 2019. Para tanto, foram selecionados, a fim de cumprir o objetivo proposto no trabalho, os comerciais: (1) Marta \#ElaÉNúmero1 ${ }^{7}$, (2) Andressa Alves' Story e (3) Copa do Mundo Feminina da FIFA ${ }^{9}$, os quais serão descritos na seção seguinte.

Nessa perspectiva, podemos observar a presença e influência da mídia em vários momentos da vida cotidiana e o modo como ela atua, construindo novos significados e gerando experiências para a vida e cultura da sociedade. Silverstone (2014) afirma que a mídia está presente em todos os aspectos de nossa vida, e que não podemos escapar a ela. Para o autor, a mídia utiliza-se de três principais maneiras para atingir e se aproximar do espectador: a retórica, linguagem utilizada para influenciar e persuadir o espectador à ação; a poética, sendo as diferentes formas de narrativas, sejam elas orais, escritas ou imagéticas; e o erotismo, recurso utilizado pela mídia para atrair e produzir o desejo do espectador. Podemos entender, portanto, o poder exercido pela mídia na sociedade em diferentes tipos de ligação estabelecidos por ela: "trata-se do poder da mídia de criar e sustentar significados; de persuadir, endossar, reforçar” (SILVERSTONE, 2014, p. 263).

Isto posto, o presente estudo está estruturado da seguinte forma: inicialmente, apresentam-se os procedimentos metodológicos adotados. Após, exibe-se a fundamentação teórica do estudo, alicerçada em dois eixos principais: a publicidade como narrativa e, também, o mito e suas definições. Na sequência, são expostas as análises elencadas para o estudo, divididas em três subseções que representam cada um dos comerciais discutidos. Por fim, têm-se as considerações finais e as referências utilizadas no desenvolvimento do trabalho.

\footnotetext{
7 Disponível em: <https:/www.youtube.com/watch?v=NYrwAODnMLY>. Acesso em: 10 fev. 2020. ${ }^{8}$ Disponível em: <https://www.youtube.com/watch?v=6Z5ugchrwsw\&t=7s>. Acesso em: $10 \mathrm{fev}$. 2020.

9 Federação Internacional de Futebol, órgão máximo do esporte no mundo.
} 


\section{VOZES $_{\text {\&IÁLORO }}^{\mid}$}

Itajaí, V. 20, n.01, jan-jun 2021

\section{Procedimentos metodológicos}

Quanto a sua tipologia, este trabalho utiliza-se das pesquisas Exploratória (objetivos), Bibliográfica e Estudo de Caso (procedimentos técnicos) e Qualitativa (abordagem do problema), baseando-se, para isso, em Prodanov e Freitas (2013), Lakatos e Marconi (2017), Gil (2012) e Yin (2015). No que tange à coleta de dados, visando cumprir o objetivo elencado, selecionaram-se, para esta pesquisa, os seguintes comerciais: (1) Marta \#ElaÉNúmero ${ }^{10}$, (2) Andressa Alves' Story ${ }^{11}$ e (3) Copa do Mundo Feminina da FIFA ${ }^{12}$.

No primeiro comercial, a jogadora de futebol Marta, da Seleção Brasileira, escreve uma carta para ela mesma do passado, quando tinha 14 anos de idade em sua terra natal Dois Riachos (AL). O comercial começa lembrando que, há 40 anos, um decreto proibia mulheres de jogar futebol profissionalmente no Brasil, e mesmo assim a melhor jogadora de futebol do mundo é uma brasileira. Marta reúne conquistas históricas nunca alcançadas no esporte. Na sequência, Marta narra uma carta escrita por ela, com palavras de incentivo e imagens mostrando as dificuldades de sua carreira e os sonhos que realizou. O comercial trata de valorizar a história incrível da atleta no esporte e celebrar os momentos que realmente importam.

Já no segundo comercial, a personagem principal é Andressa Alves, que relembra sua história quando criança, enfrentando desafios na infância. O comercial é nomeado de “Andressa Alves' Story” e enfatiza as inúmeras vezes em que a jogadora ganhou uma boneca, quando o que ela queria era uma bola de futebol. Enxergando uma oportunidade naquele cenário, a jogadora encontrou uma maneira de adaptar seus brinquedos para brincar com o que realmente gostava. Andressa mudou sua realidade e passou a jogar futebol com a cabeça de suas bonecas, que ela arrancava para transformar em bolas de futebol. O comercial termina com a frase "Não mude o seu sonho. Mude o mundo".

Por fim, o terceiro comercial trata de ressaltar a maior competição da vida das atletas brasileiras. Marta, a camisa 10 da Seleção Brasileira, eleita seis vezes a melhor do mundo, é uma das estrelas que participa ao lado das jogadoras Bia, Debinha, Mônica e Tamires. O comercial busca ressaltar, além da modalidade, flashes emocionantes de jogos, conquistas e treinos com muita dedicação, entrega e paixão de cada uma das jogadoras em suas carreiras, com o mote "Aqui é Copa do Mundo".

A fim de demonstrar, graficamente, momentos importantes em cada um dos comerciais selecionados, (re)viu-se os mesmos e, em instantes considerados fundamentais

\footnotetext{
10 Disponível em: <https:/www.youtube.com/watch?v=NYrwAODnMLY>. Acesso em: 10 fev. 2020.

"Disponível em: <https://www.youtube.com/watch?v=6Z5ugcnrwsw\&t=7s $>$. Acesso em: 10 fev. 2020.

${ }^{12}$ Disponível em: <https://www.youtube.com/watch?v=OgObXdgV_14>. Acesso em: 13 fev. 2020
} 


\section{VOZES $_{\text {\&IÁLORO }}^{\mid}$}

Itajaí, V. 20, n.01, jan-jun 2021

para a construção da narrativa, parou-se o vídeo e aplicou-se a tecla print screen, buscando "congelar" o específico tempo. O quadro a seguir, por isso, demonstra esses keyframes ${ }^{13}$ selecionados em cada um dos comerciais, assim como seu respectivo tempo inicial.

Quadro 1: Keyframes selecionados

\begin{tabular}{|c|c|c|}
\hline Comercial & Keyframe & Tempo inicial \\
\hline Brahma & $\begin{array}{l}\text { O frame enfatiza que a jogadora } n^{\circ} 1 \text { do } \\
\text { mundo é uma brasileira. }\end{array}$ & $00: 07$ \\
\hline Brahma & $\begin{array}{l}\text { Marta aparece em um campo de futebol } \\
\text { olhando crianças brincando, lembrando de } \\
\text { seus desafios do passado. }\end{array}$ & $00: 38$ \\
\hline Brahma & $\begin{array}{l}\text { É possível ver Marta driblando e fazendo } \\
\text { gols, com a camisa da Seleção Brasileira, } \\
\text { pela qual torna-se recordista de gols. }\end{array}$ & $01: 18$ \\
\hline Brahma & $\begin{array}{l}\text { Em cerimônia realizada pela Fifa, Marta é } \\
\text { eleita a melhor jogadora do mundo pela } \\
\text { sexta vez. }\end{array}$ & $01: 25$ \\
\hline Brahma & Semblante de realização no rosto de Marta. & $01: 55$ \\
\hline Nike & $\begin{array}{l}\text { Na janela, Andressa sorri, enquanto criança, } \\
\text { olhando meninos jogando futebol. }\end{array}$ & $00: 26$ \\
\hline Nike & $\begin{array}{l}\text { Andressa corre na rua com sua boneca nos } \\
\text { braços. }\end{array}$ & $00: 38$ \\
\hline Nike & $\begin{array}{l}\text { A cabeça de uma boneca é utilizada como } \\
\text { uma bola de futebol. }\end{array}$ & $00: 47$ \\
\hline Nike & $\begin{array}{l}\text { Olhar determinado da jogadora quando } \\
\text { criança praticando a brincadeira que } \\
\text { gostava. }\end{array}$ & $00: 50$ \\
\hline Nike & $\begin{array}{l}\text { Andressa exibe suas habilidades com a bola } \\
\text { de futebol, e o comercial termina com a } \\
\text { frase "Não mude o seu sonho. Mude o } \\
\text { mundo". }\end{array}$ & $00: 57$ \\
\hline Sportv & $\begin{array}{l}\text { Marta driblando a adversária com grande } \\
\text { habilidade. }\end{array}$ & $00: 21$ \\
\hline Sportv & $\begin{array}{l}\text { Jogadoras comemorando abraçadas com } \\
\text { sorrisos nos rostos em um campo de } \\
\text { futebol. }\end{array}$ & $00: 30$ \\
\hline Sportv & $\begin{array}{l}\text { O sofrimento, cansaço estampado no rosto } \\
\text { da jogadora. }\end{array}$ & $00: 44$ \\
\hline
\end{tabular}

\footnotetext{
${ }^{13}$ Em português, quadros-chave. Imagem audiovisual paralisada.
} 
Itajaí, V. 20, n.01, jan-jun 2027

\begin{tabular}{|l|l|l|}
\hline Comercial & Keyframe & Tempo inicial \\
\hline Sportv & $\begin{array}{l}\text { Treinando com garra e determinação, a } \\
\text { jogadora mostra-se focada em uma } \\
\text { academia. }\end{array}$ & $00: 50$ \\
\hline Sportv & $\begin{array}{l}\text { Seleção Brasileira Feminina vibrando juntas } \\
\text { por mais uma conquista. }\end{array}$ & $00: 53$ \\
\hline
\end{tabular}

Fonte: Elaborado pelos autores

A etapa seguinte, de análise desses momentos-chave, baseou-se nos estudos de Barthes (1990), através da Retórica da Imagem. Para o referido autor, em publicidade, o uso da imagem é, propositalmente, intencional. Determinados atributos do produto constituem à priori os significados da mensagem publicitária, sendo estes transmitidos da forma mais clara possível. Se, portanto, "uma imagem contém signos, teremos certeza que, em publicidade, esses signos são plenos, formados com vistas a uma melhor leitura” (BARTHES, 1990, p. 28), tornando, assim, a mensagem publicitária mais enfática.

Barthes (1990) desenvolve sua análise em imagens presentes na publicidade subdividindo-as em mensagens denotadas e conotadas. A mensagem denotada (icônica) é a representação pura das imagens apresentando os objetos da cena. Já a mensagem conotada (simbólica) envolve os aspectos simbólicos da imagem. Portanto, a técnica proposta por Barthes (1990) encontra-se em um "sistema que adota os signos de outro sistema, para deles fazer seus significantes, sendo um sistema de conotação, podemos, pois, desde já afirmar que a imagem literal é denotada, e a mensagem simbólica é conotada” (BARTHES, 1990, p. 31).

\section{A publicidade como narrativa}

Compreende-se a narrativa como uma série de acontecimentos que, juntos, contam uma história real ou imaginária. Conforme Barthes et al. (2011, p. 19), “inumeráveis são as narrativas do mundo”, e o autor complementa dizendo que a narrativa está presente em todos os tempos, em todas as sociedades e em diferentes culturas. A narrativa se inicia com a própria história da humanidade, tornando-se presente no mito, na fábula, na lenda, no cinema, na novela, nos filmes, entre tantos outros tipos de obras narrativas. Neste contexto, estas narrativas utilizadas em anúncios publicitários estão, cada vez mais, frequentemente no cotidiano dos espectadores, pois permitem que estes vivam o anúncio através de uma história. Atualmente, marcas desenvolvem campanhas buscando contar histórias, de forma a compartilhar emoções, objetivos e valores, assim, criando relações a longo prazo com seus consumidores. Deste modo, Camargo (2016) e Bharadwaj et al. (2020) afirmam que os espectadores já não consomem somente os produtos anunciados, e sim consomem, também, mensagens publicitárias. 


\section{VOZES $_{\text {\&IÁLORO }}^{\mid}$}

Itajaí, V. 20, n.01, jan-jun 2021

A narrativa publicitária, para Camargo (2016), é fantástica, e o fantástico pode ser entendido, portanto, como significado, algo que dá vida, alma, nome, personalidade e história ao produto anunciado, no qual este se conecta ao seu consumidor através da relação próxima que a narrativa desenvolve. Logo, a publicidade quanto mais fantástica for, mais o produto tem força. Para Baudrillard (2000, p. 175), "não mais se trata de uma lógica do enunciado e da prova, mas sim de uma lógica da fábula e da adesão”. O público, sem crer no produto, crê na publicidade que o faz desejá-lo. O autor, por sua vez, adverte que de nada adianta resistir à publicidade, pois, à medida que resistimos, nos tornamos mais sensíveis a sua existência.

A capacidade de narrar é um aspecto do ser humano e, para Zheng, Phelps e Pimentel (2019), a narrativa publicitária está presente no cotidiano do homem, promovendo desejos, necessidades de consumo, quer seja em produtos, ideias ou serviços. A estrutura da narrativa publicitária é metodicamente construída, para os autores, e a construção de boas histórias é essencial para gerar empatia e diálogo com o receptor, mas estes advertem sobre o uso correto de palavras e significados, pois, de maneira incorreta, pode-se interpretá-los de modo não pretendido. Desta forma, a publicidade, enquanto narrativa, destaca os vários recursos da linguagem audiovisual para atingir o receptor através de histórias curtas, porém densas e abundantes em simbolismo.

De acordo com Silva e Covaleski (2016), a publicidade atual aposta em uma relação afetiva com o público, através de uma narrativa envolvente para conquistá-lo. É por meio das narrativas publicitárias que os sentidos são construídos e os valores materializados em bens de consumo. Dessa maneira, a narrativa tem um papel relevante na construção do processo de significação dos anúncios. Diferente da publicidade mais tradicional, com seu uso exclusivo de caráter informativo, a publicidade contemporânea se utiliza da retórica, a qual tem como objetivo o envolvimento emocional do público. De modo geral, a narrativa publicitária trata de conquistar esse público que exige muito mais que bens de consumo, e sim sensações e experiências. Observa-se que anúncios que recorrem ao uso dessa retórica aumentam a eficácia da comunicação, que consiste em um possível envolvimento emocional com o receptor. Para Bharadwaj et al. (2020), a publicidade atual se adapta às exigências mercadológicas diante de um contexto social que vivencia e valoriza a diferença.

\section{O mito e suas definições}

O mito, nos dias atuais, é um modelo de referência e projeção de alguém, uma personalidade que enfrenta uma história de luta e leva consigo a marca da vitória. Rubio (2001, p. 79) o define como um "discurso mítico que dispõe em cena personagens, situações, cenários geralmente não naturais, segmentável em reduzidas unidades semânticas nas quais, de modo necessário, está investida uma crença” e compreende que a estrutura e função dos mitos nas sociedades "não é apenas explicar uma etapa na história 


\section{VOZES $_{\text {\&IÁLORO }}^{\mid}$}

Itajaí, V. 20, n.01, jan-jun 2021

do pensamento humano, é também compreender melhor uma categoria dos nossos contemporâneos" (RUBIO, 2001, p. 78). Camargo (2016) cita o mito como uma narrativa e o nomeia como uma narrativa fantástica que está atrelada a personagens reais, pessoas com papel significativo na sociedade, que geralmente são vinculados a ídolos, esportistas, modelos, entre outros. Assim, o mito passa a ser uma história repleta de imagens, lugares e personagens marcantes a serem inseridos por meio da publicidade.

Eliade (1972) e Lloyd (2018), sob outro viés, entendem que o mito apresenta uma história sagrada, uma realidade cultural extremamente complexa na qual sua narrativa acontece no tempo primordial, o tempo fabuloso do "princípio". O mito transforma-se, portanto, em um modelo exemplar para a conduta de todas as atividades humanas significativas, como a alimentação, o casamento, o trabalho, a educação, a arte ou a sabedoria, sendo essa sua principal função. Eliade (1972, p. 13) diz que, para o homem arcaico, o mito é "uma questão da mais alta importância, ao passo que os contos e as fábulas não o são”. Dessa maneira, o homem arcaico se proclama o resultado de um certo número de eventos míticos, e o homem moderno se considera constituído pela história. Em suma, "conhecer os mitos é aprender o segredo da origem das coisas. Em outros termos, aprendese não somente como as coisas vieram à existência, mas também onde encontrá-las e como fazer com que reapareçam quando desaparecem” (ELIADE, 1972, p. 14).

Campbell e Moyers (2014, p. 6) considera que a definição de mito é a experiência de vida e que os mitos "são pistas para as potencialidades espirituais da vida humana"; logo, essas experiências de vida ganham significado mitológico, o que Barthes (2001) trata como o estudo de uma fala sendo apenas um fragmento dessa vasta ciência dos signos. Segundo o autor, o mito é uma fala, mas não uma fala qualquer: "são necessárias condições especiais para que a linguagem se transforme em mito” (BARTHES, 2001, p. 131).

O mito, ao mesmo tempo que é uma fala, pode ser caracterizado como uma mensagem; sendo assim, tudo pode ser considerado mito, desde que seja suscetível de ser julgado por um discurso. Entretanto, "o mito é um sistema particular, visto que ele se constrói em cima de uma cadeia semiológica que existe já antes dele: é um sistema semiológico segundo" ou seja, o mito resulta da junção de um significante e um significado dando origem a um signo (BARTHES, 2001, p.136) que, por sua vez, é o encontro de um conceito e de uma imagem. Barthes (2001) produz, ainda, um esquema para explicar de forma mais clara a relação dos três termos na linguagem e no mito: o significante, o significado e o signo. 


\section{VOZES $_{\text {\&DÁLORO }}^{\mid}$}

Itajaí, V. 20, n.01, jan-jun 2027

Figura 1: Representação da cadeia semiológica do mito barthesiano

\section{CADEIA SEMIOLÓOICA DO MITO BARTHESIANO}

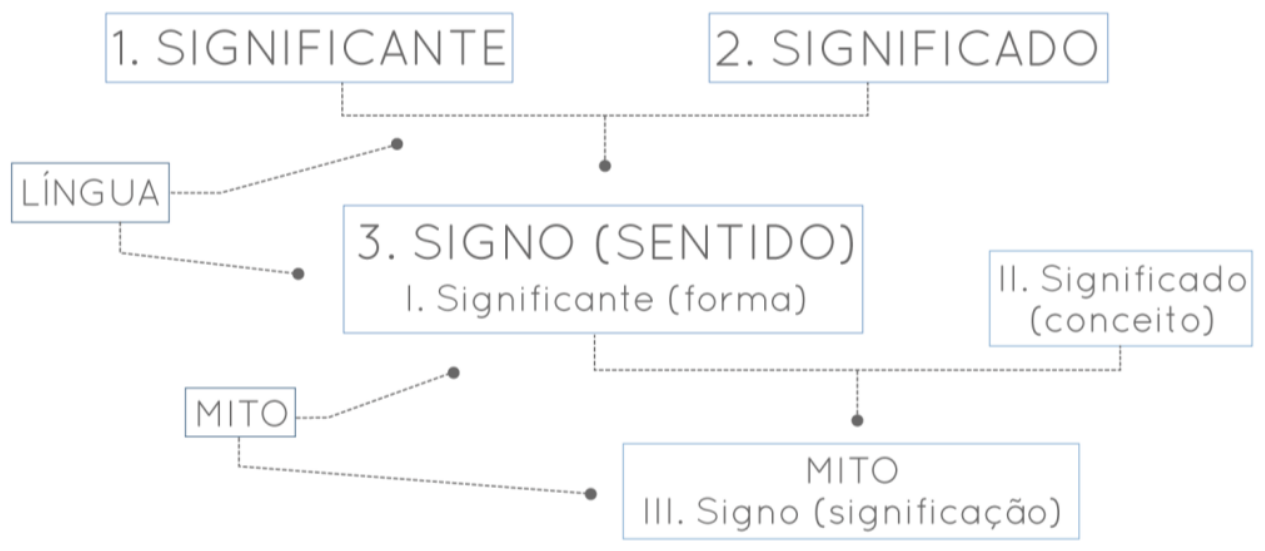

Fonte: Elaborado pelos autores, com base em Barthes et al. (2011)

De um modo lúdico, pode-se visualizar, através da figura 1, que o mito é formado por dois sistemas semiológicos: a língua, que Barthes (2001) nomeia como linguagemobjeto (que é de onde o mito constrói seu próprio sistema), e o próprio mito como sendo metalinguagem, pois o mito nada mais é do que uma segunda língua, na qual se fala da primeira. Barthes (2001), portanto, exemplifica, através do seu conceito, que o mito é, então, estabelecido a partir de um signo primeiro (denotativo) que serve como significante para um segundo signo, do qual seu significado é intencional, mas que se oculta por meio do primeiro signo, que se exibe como uma descrição inocente dos fatos.

Em complemento, Lisboa (2018) e Rowe (2018) compreendem o mito como uma narrativa simbólica que apresenta modelos para a vida humana sobre uma significação e um valor existencial, que não se resume, apenas, em pura fantasia, e sim em um modo de pensamento para compreender o mundo e sentir a realidade. A partir daí, o mito é visto como uma verdade que contribui no processo de compreensão da realidade em si, dentro do cotidiano. Compreender o mito é uma tarefa complexa, que Lisboa (2018, p. 27) nomeia como um "conhecimento da realidade espiritual e cultural do ser humano, que se apresenta no campo simbólico e literário. A consciência mítica está em qualquer época”.

Desta forma, então, faz-se necessário identificar essa consciência mítica em nossos tempos atuais, em que a cultura científica é dita como uma verdade em se tratando do sentido existencial do ser humano, possivelmente reconhecendo os mitos do passado; assim, é possível analisar as condições de vida contemporâneas, em frente ao contraste histórico (LISBOA, 2018; TUASTAD, 2019). 


\section{VOZES $_{\text {\&IÁLORO }}^{\mid}$}

Itajaí, V. 20, n.01, jan-jun 2021

\section{A construção das atletas de ouro}

Apresentam-se, a seguir, as análises propostas para os comerciais selecionados.

\section{MARTA \#ELAÉNÚMERO1}

Inicialmente, observa-se, no comercial selecionado, o impacto da frase sobre a luta de um longo período de proibição, preconceito e quebra de barreiras na história do futebol feminino no Brasil. Na imagem em questão - primeiro keyframe da Figura 2 -, identificase a frase que ressalta que há 40 anos o futebol no Brasil era considerado, por decreto, uma prática inapropriada para mulheres e, após o seu fim, a jogadora número 1 do mundo foi uma brasileira. Apesar do aspecto visual escuro do keyframe que endossa a frase mencionada - o que pode criar, portanto, um certo ambiente negativo -, há, sim, uma exaltação do poder da fala que, combinado com o branco, demonstra força e, ainda, legibilidade no momento da leitura.

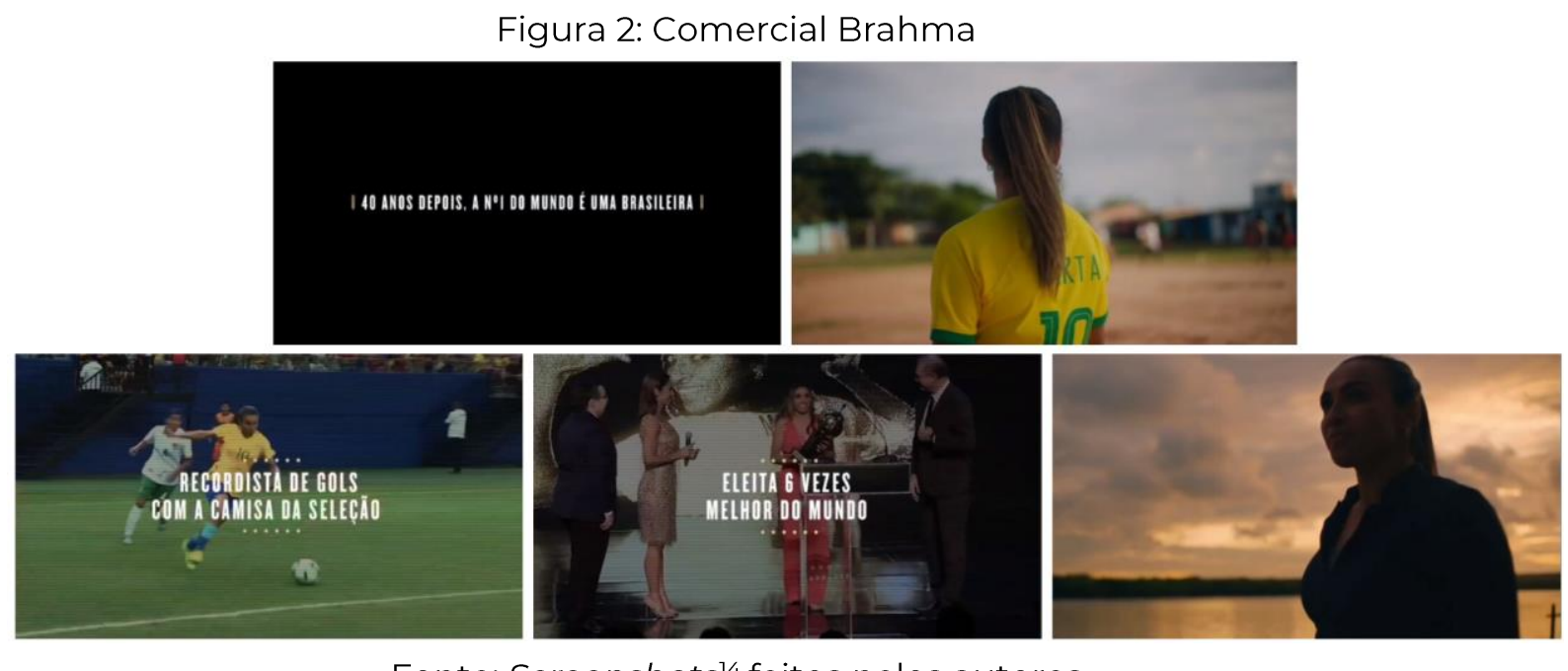

Fonte: Screenshots ${ }^{14}$ feitos pelos autores

Na sequência, a peça publicitária objeto deste estudo mostra Marta vestindo a camisa 10 da Seleção Brasileira; a jogadora está com o cabelo preso e de costas para a cena. Ao lado direito da imagem, é possível observar meninos jogando futebol em um campo de terra. A ambientação da imagem consiste em uma visão mais ampla do cenário, promovendo, assim, um sentido de isolamento da personagem principal Marta. Também ao fundo da imagem enxergam-se algumas árvores, um céu aberto e casas, características que remetem a um local familiar à personagem mencionada. A cenografia, como um todo, contribuiu, destarte, para estabelecer uma atmosfera de lembranças de momentos vividos por Marta no passado.

\footnotetext{
${ }^{14}$ Em português, captura de tela.
} 


\section{VOZES $_{\text {\&IÁLORO }}^{\mid}$}

Itajaí, V. 20, n.01, jan-jun 2021

Em seguida, o comercial retrata a imagem da jogadora em questão atuando em jogos oficiais pela Seleção Brasileira. O cenário, por óbvio, é um campo de futebol, em que o plano usado permite ver a torcida e um homem (árbitro assistente) atentos ao lance. É possível perceber na cena, ainda, a dificuldade da jogadora adversária ao tentar alcançar Marta. Ganham destaque no contexto narrativo, também, os dribles e gols da jogadora que são evidenciados nos letterings $s^{15}$ da cena.

Em complemento à imagem anterior, o keyframe 4 da Figura 2 mostra a brasileira em uma cerimônia oficial realizada pela Fifa, na qual Marta se tornou a maior vencedora do prêmio individual na história do futebol. No plano mais distante da imagem, enxergase a jogadora em um telão, sorrindo de costas e apontando para a própria camisa em sinal de reverência a sua marca alcançada. Na imagem estão presentes quatro pessoas, sendo uma mulher e dois homens e, ainda, Marta, que recebe o troféu de melhor jogadora do mundo. Os letterings evidenciam que Marta conquistou o prêmio seis vezes.

No fim do comercial, representado pelo último keyframe da Figura 2, há uma menção ao momento em que Marta retorna a sua cidade natal - Dois Riachos (Alagoas). O enquadramento utilizado consiste em evidenciar certas expressões e semblantes ressaltando a emoção da cena, onde a personagem se destaca na maior parte da área enquadrada, e os demais elementos, como a margem do rio, árvores, nuvens e o céu, compõem o cenário. A luz solar salienta os tons quentes na imagem, aumentando, assim, a intensidade e a força da personagem em cena.

Dessa forma, considerando a narrativa utilizada no comercial, constata-se a intenção de retomar a história de vida da camisa 10 da Seleção Feminina de futebol, ícone no esporte, dentro e fora dos gramados. Sua trajetória de vida é marcada por grandes obstáculos, desafios e uma infância pobre, ferida com sua saída precoce de casa para a luta por um sonho com diversos momentos de superação e dificuldades na vida e no esporte, até alcançar uma vitoriosa carreira.

Nesse contexto, é possível identificar, conforme mencionado por Camargo (2016), uma narrativa fantástica, que, atrelada a uma personagem da vida real, torna-se uma personalidade próxima do espectador. A narrativa de Marta se inicia com sua própria história, de forma a compartilhar suas emoções, dificuldades, conflitos e sucesso, conectando-se através de uma relação próxima do público que a narrativa evidencia.

O sucesso de Marta, segundo a narrativa usada, não foi acidental, visto que ela própria narra o esforço concentrado na sua construção no esporte. O talento de Marta "deixa para trás" as adversárias com grandes dribles e toques audaciosos, e sua habilidade

\footnotetext{
${ }^{15}$ Em português, letras. Lettering pode ser definido como a arte de desenhar e criar letras que servem para um objetivo, uma utilização específica e uma finalidade.
} 


\section{VOZES $_{\text {\&DÁLORO }}^{\mid}$}

Itajaí, V. 20, n.01, jan-jun 2021

em jogos é, conforme demonstrado, incomparável e única - em sua carreira vitoriosa, Marta marcou centenas de gols ${ }^{16}$ e tornou-se recordista pela Seleção Brasileira Feminina.

O comercial busca ressaltar que a atleta, por sua vez, sempre permaneceu lutando dentro e fora dos gramados; foram anos de dedicação com muita garra, determinação e persistência, até tornar-se a maior campeã da história da premiação da Fifa. A brasileira continuou quebrando recordes, tornando-se a jogadora mais vezes eleita melhor do mundo, um recorde entre mulheres e homens, superando e igualando grandes nomes do futebol masculino, como Cristiano Ronaldo e Lionel Messi ${ }^{-17}$, respectivamente.

Em sua narrativa, a peça publicitária busca demonstrar que a participação em grandes torneios e competições levaram uma mulher simples e de origem humilde a feitos inéditos e históricos. Marta mudou o esporte e sua história: o talento e o sucesso atingidos são prova de uma biografia de luta, que leva consigo a marca da vitória. E essa história narrada se mostra miticamente verdadeira quando se refere às realidades vividas pela jogadora; e isso, segundo Rubio (2001), é uma característica latente em um mito no esporte e na vida, um modelo de referência e projeção a milhares de espectadores que acompanham atletas.

Dessa maneira, Marta estabelece modelos de comportamento humano e personalidade e serve de inspiração para outros mitos que virão depois dela. Acentuando, portanto, a questão, Eliade (1972) e Lloyd (2018) destacam a função do mito como um modelo exemplar na conduta de todas as atividades humanas significativas e, assim, Marta se firma como um mito nas suas atividades, como no trabalho, no esporte, na educação e em toda sua trajetória de vida.

Quadro 2 - Quadro-Síntese

\begin{tabular}{|l|l|}
\hline \multicolumn{2}{|c|}{ Comercial Brahma } \\
\hline Viés denotado & Viés conotado \\
\hline $\begin{array}{l}\text { Cena com tela na cor preta que exalta o poder } \\
\text { da frase inserida na imagem: "40 anos depois, } \\
\text { a nº do mundo é uma brasileira". }\end{array}$ & $\begin{array}{l}\text { Remete-se à quebra de um decreto no futebol } \\
\text { feminino e ao ápice da jogadora da Seleção } \\
\text { Feminina do Brasil. }\end{array}$ \\
\hline $\begin{array}{l}\text { Marta está de costas e veste a camisa 10 da } \\
\text { brinçando Brasileira; é possível ver crianças }\end{array}$ & $\begin{array}{l}\text { Refere-se à lem um crança de sua trajetória } \\
\text { marcada por obstáculos e desafios até } \\
\text { alcançar sua carreira de sucesso. }\end{array}$ \\
\hline $\begin{array}{l}\text { Em jogos oficiais da Seleção Brasileira, Marta } \\
\text { exibe suas habilidades e gols na carreira. }\end{array}$ & $\begin{array}{l}\text { Alude-se ao talento, ao esforço e à habilidade } \\
\text { da jogadora na construção de sua carreira } \\
\text { vitoriosa. }\end{array}$ \\
\hline
\end{tabular}

\footnotetext{
${ }^{16}$ Até a finalização deste trabalho, Marta já havia marcado 431 gols por 11 clubes diferentes, incluindo a Seleção Brasileira.

${ }^{17}$ Cristiano Ronaldo foi eleito o melhor jogador do mundo pela FIFA um total de cinco vezes, e Lionel Messi foi eleito o melhor jogador do mundo pela FIFA um total de seis vezes.
} 


\section{${ }_{\text {VOZES }}^{\mid}$DILORO}

Itajaí, V. 20, n.01, jan-jun 2021

\begin{tabular}{|l|l|}
\hline $\begin{array}{l}\text { Marta torna-se a maior vencedora: eleita 6 } \\
\text { vezes a melhor do mundo em cerimônia } \\
\text { realizada pela Fifa. }\end{array}$ & $\begin{array}{l}\text { Relaciona-se ao momento de conquista, após } \\
\text { ter enfrentado muitos obstáculos em sua } \\
\text { trajetória. Transmite também a sensação de } \\
\text { sucesso dessa atleta ícone no esporte. }\end{array}$ \\
\hline $\begin{array}{l}\text { Com sorriso tímido no rosto é possível ver } \\
\text { Marta em sua cidade natal. }\end{array}$ & $\begin{array}{l}\text { Menciona-se o sentimento de conquista, de } \\
\text { façanha. Uma carreira, uma história de vida } \\
\text { incrível que ressalta a sua capacidade de } \\
\text { acreditar em si, persistência e determinação. }\end{array}$ \\
\hline
\end{tabular}

Fonte: Elaborado pelo autores

\section{ANDRESSA ALVES' STORY}

"Eu nunca pedi uma boneca, mas já perdi as contas de quantas já ganhei”, narra a atleta Andressa Alves no início do comercial publicitário selecionado. No contexto narrativo da peça publicitária, retrata-se, em um primeiro momento, a jogadora de futebol em questão quando criança, atenta, observando, em cima de uma poltrona, pela janela de sua casa, meninos jogando futebol na rua. Ou seja, o que está sendo visto na cena é, na verdade, apenas uma memória da personagem, que relembra momentos de sua infância. Infância essa que foi marcada desde muito cedo por um sonho, um objetivo, tornar-se uma jogadora de futebol profissional. No decorrer das primeiras cenas do comercial, é possível ver a relação de Andressa com suas bonecas e o esporte; em um plano fechado, mostra-se, ainda, a criança Andressa admirando tal situação: uma roda de meninos jogando futebol.

Figura 3: Comercial Nike
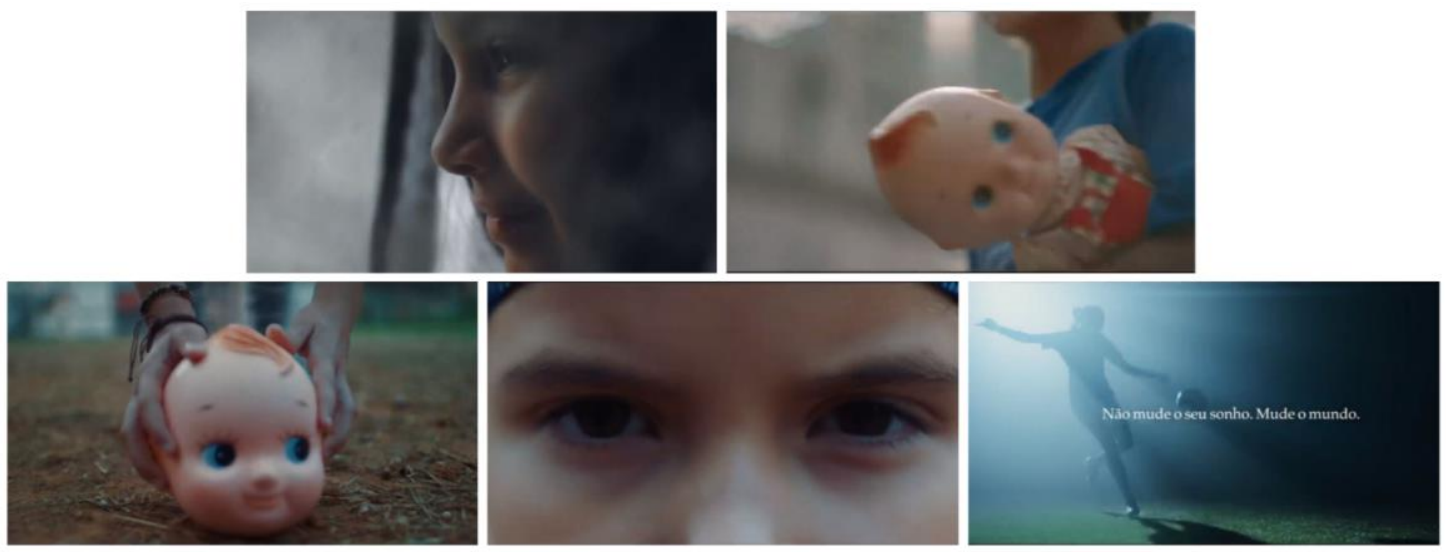

Fonte: Screenshots feitos pelos autores

Assim, percebe-se a mesma questão no decorrer do comercial - cujos keyframes estão expostos na Figura 3 -, no qual Andressa é vista com uma de suas bonecas nos braços, correndo em direção a um campo de futebol de terra. A atleta, ainda criança, com seu longo cabelo preso e tiara, veste uma camisa azul, bermuda branca, meiões azuis claros e um par de tênis em velcro também na cor azul, da marca Nike. A boneca em questão é exibida em plano detalhe, o que evidencia sua falta de cabelo. Na sequência, vê-se 


\section{VOZES $_{\text {\&IÁLORO }}^{\mid}$}

Itajaí, V. 20, n.01, jan-jun 2021

novamente, em um plano detalhe, apenas a cabeça da boneca. Podemos observar, então, que Andressa encontra-se em um campo de futebol, ambiente onde meninos costumam, culturalmente, jogar futebol.

Percebe-se que a boneca que estava em seus braços foi adaptada para se tornar uma bola de futebol. As mãos de Andressa, então, são exibidas, assim como a cabeça de sua boneca. O campo de futebol, como se pode observar, é de terra, o que torna o ambiente de uma certa forma simples, comparando-o com grandes estádios de futebol. Nota-se, ainda, as mãos de Andressa, posicionando a cabeça de sua boneca para usá-la como bola de futebol, iniciando, assim, seus treinos em forma de brincadeira. Sua relação com os brinquedos, em particular suas bonecas, em um primeiro momento, pode parecer peculiar, haja vista a maneira que Andressa encontrou para transformar o brinquedo em algo que realmente a interessava: bola de futebol.

Em sua continuidade, a peça exibe, mais uma vez, em plano detalhe, Andressa. $\mathrm{O}$ comercial trata de evidenciar os olhos da pequena criança que, ao brincar, apresenta toda sua força e determinação em busca do seu sonho. Nesse momento, o comercial selecionado ganha mais força expressiva em sua fotografia, despertando um tom emocional e reforçando a atmosfera de memória representada na expressão visual de Andressa. Já em seu momento final, a atleta da Seleção Feminina de futebol retorna ao comercial publicitário já como jogadora profissional. Pode-se observar que seu uniforme relembra suas roupas de brincar na infância, além do cabelo preso, tiara, camisa azul, bermuda branca, meiões azuis e sua chuteira da marca Nike. Com o mesmo olhar de força e determinação, Andressa é vista em diversos enquadramentos exibindo, portanto, toda sua habilidade com a bola. Na cena em evidência, a atleta narra: "nada contra as bonecas, era só que eu preferia a bola”. Identifica-se, ao final da peça publicitária, em letterings, a frase: "Não mude o seu sonho. Mude o mundo".

O comercial publicitário nomeado "Andressa Alves' Story” reconta a história da jogadora com o esporte de forma a mostrar dificuldades enfrentadas para se tornar uma atleta profissional de futebol. Na infância, Andressa era presenteada com bonecas, brinquedo considerado, por muitos, mais adequado para o sexo feminino; no entanto, a jogadora não queria ganhar bonecas de presente, mas, sim, uma bola. Porém, essa realidade não a impediu de realizar seu sonho: as cabeças de suas bonecas foram transformadas, pela própria jogadora, em bola. Seus chutes no brinquedo adaptado fortaleceram sua trajetória em busca da profissionalização no futebol.

A experiência de vida pode ser considerada algo mítico, segundo Campbell e Moyers (2014), bem como a emblemática trajetória da Andressa, assim, tais experiências de vida ganham significado, já que, para Barthes (2001), o mito é visto como um sistema particular construído através de uma cadeia semiológica. A peça publicitária reforça, portanto, a construção do mito Barthesiano (2001) na história da jogadora de futebol Andressa. Percebe-se no comercial, em consequência disso, um significante (forma) que 


\section{VOZES $_{\text {\&IÁLORO }}^{\mid}$}

Itajaí, V. 20, n.01, jan-jun 2021

podemos ver no brinquedo em questão: as bonecas da jogadora, em especial aquelas que não possuíam cabelo. Andressa então, para transformar suas bonecas em bolas de futebol, utilizava sua imaginação e criatividade: para que pudesse entender o significado (conceito), pegava uma boneca e fazia de sua cabeça uma bola de futebol. A partir daí, o mito passa a ser visto como a significação, que na peça publicitária é a transformação de um brinquedo que contribuiu para a realização de um sonho em um brinquedo que, hoje, é sua profissão.

Se, ainda na infância, Andressa teve que improvisar as primeiras jogadas como esportista hábil e criativa que é, para alcançar sua almejada carreira futebolística não foi diferente. Silva e Covaleski (2016) destacam que as narrativas contadas através da publicidade constroem relações afetivas com o receptor, assim, frente à emocionante história, observa-se o quão envolvente e atraente é o comercial publicitário selecionado. A atleta, que sonhava em ter uma bola de futebol, nos mostra, em detalhes, desafios enfrentados, imaginação e garra na busca de seus sonhos e muito esforço para hoje representar o futebol brasileiro pelos gramados do mundo.

Quadro 3 - Quadro-Síntese

\begin{tabular}{|l|l|}
\hline \multicolumn{2}{|c|}{ Comercial Nike } \\
\hline Viés denotado & Viés conotado \\
\hline $\begin{array}{l}\text { Andressa encontra-se sorrindo observando } \\
\text { pela janela de sua casa meninos jogando } \\
\text { futebol na rua. }\end{array}$ & $\begin{array}{l}\text { Lembrança de uma infância marcada por } \\
\text { brincadeiras, sorrisos e desde muito cedo um } \\
\text { sonho. Uma relação muito forte com o esporte. }\end{array}$ \\
\hline $\begin{array}{l}\text { Andressa corre em direção a um campo de } \\
\text { futebol com uma de suas bonecas nos braços. }\end{array}$ & $\begin{array}{l}\text { Representa a busca constante de um sonho, } \\
\text { construção de sua trajetória. }\end{array}$ \\
\hline $\begin{array}{l}\text { As mãos de Andressa são exibidas, } \\
\text { posicionando a cabeça de sua boneca no na } \\
\text { campo de futebol em direção à goleira. }\end{array}$ & $\begin{array}{l}\text { Refere-se à transformação de um brinquedo } \\
\text { ao ter parte dele como um objeto desejado, } \\
\text { fazendo da imaginação sua luta. }\end{array}$ \\
\hline $\begin{array}{l}\text { É exibido em plano detalhe o rosto de } \\
\text { Andressa, os olhos ganham expressão maior } \\
\text { na cena. }\end{array}$ & $\begin{array}{l}\text { Remete-se à expressão de um olhar cheio de } \\
\text { determinação, certezas em busca da } \\
\text { concretização de um sonho em se tornar } \\
\text { jogadora de futebol. }\end{array}$ \\
\hline $\begin{array}{l}\text { Agora como profissional, Andressa está em um } \\
\text { futebol onde demonstra suas habilidades. }\end{array}$ & $\begin{array}{l}\text { "Não mude o seu sonho. Mude o mundo". } \\
\text { Corresponde ao alcance da profissão. } \\
\text { Esportista hábil e criativa que representa a } \\
\text { Seleção Brasileira pelo mundo. }\end{array}$ \\
\hline
\end{tabular}

Fonte: Elaborado pelos autores 


\section{VOZES:

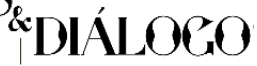

Itajaí, V. 20, n.01, jan-jun 2021

“Aqui é dedicação, é entrega, é paixão, aqui é Copa do Mundo": uma narrativa clássica que fala de superação de obstáculos, redenção e glória. Além de Marta, o comercial publicitário selecionado conta ainda com outras estrelas do Brasil, destacando o trabalho árduo das atletas através de flashes emocionantes de jogos, treinos e conquistas. Alternando-se entre diversas cenas, o início do comercial mostra Marta, a camisa 10 da Seleção Brasileira Feminina, driblando a adversária em um alto grau técnico. Ao fundo, pode ser constatado que tais flashes são ambientados em diversos estádios de futebol, em diferentes partidas. A atleta demonstra habilidades, força e agilidade nas jogadas que antecedem seus belos passes e gols. Em seguida, pode ser observado, em complemento à cena anterior, Marta abraçada em suas colegas de profissão. Em um primeiro plano destacam-se as atletas, o ápice da comemoração da vitória que se estende através de gestos e sorrisos das jogadoras. Observando a cena, é perceptível a relação de afeto entre elas em busca de um objetivo coletivo.

Figura 4: Comercial Sportv
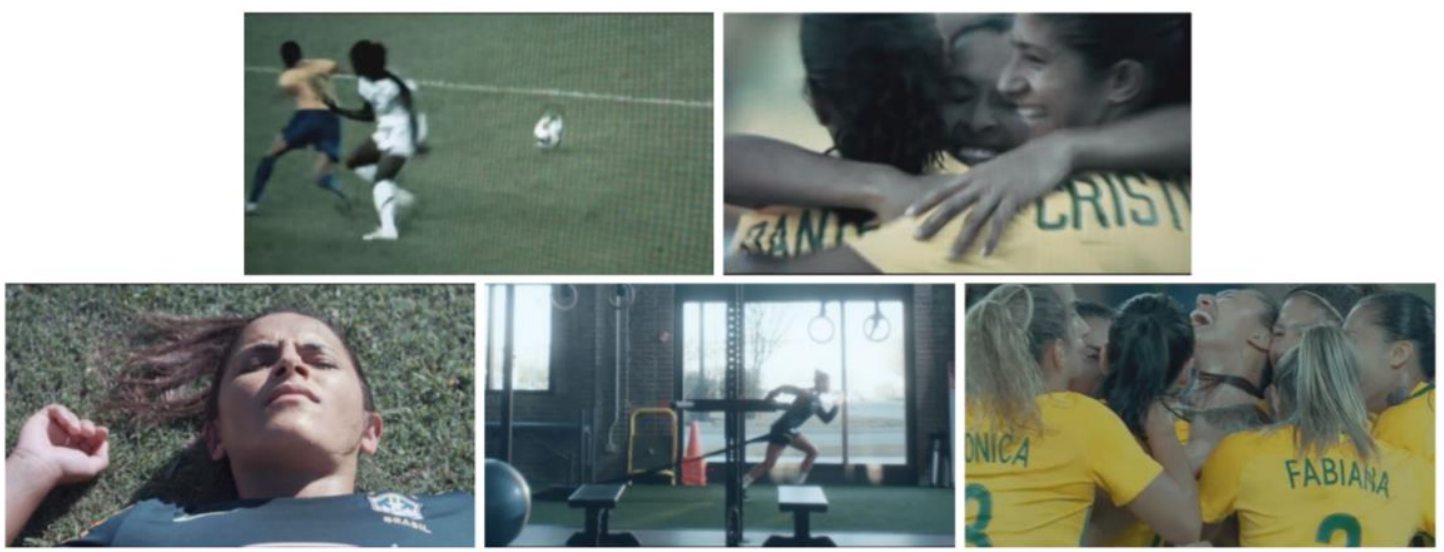

Fonte: Screenshots feitos pelos autores

No decorrer da narrativa, a cenografia contribui para revelar todos os passos que antecedem treinos, jogos, conquistas e derrotas de um(a) jogador(a) de futebol. Dessa forma, o comercial publicitário exalta vários momentos do trabalho árduo das atletas com muita entrega de cada uma durante os treinos. Pode-se perceber isto no keyframe 3 da Figura 4, no qual Débora, mais conhecida por Debinha, aparece deitada em um campo de futebol; é visível seu estado de cansaço físico, exaustão e entrega. No plano detalhe da imagem em questão, é possível ver gotas de suor em seu rosto, assim como o aspecto de dor, após mais um dia de trabalho.

A partir de então, a narrativa ressalta, em diferentes sequências, o dia a dia de treinos das jogadoras, assim, a imagem em questão retrata a atleta da Seleção Brasileira Feminina Tamires, com uniforme de treino e cabelo preso, realizando exercícios com extrema concentração e determinação. O cenário é um centro de treinamentos, onde podemos observar aparelhos de grande proporção, médios e pequenos, equipamentos e acessórios para os exercícios das atletas. Em complemento ao ambiente, existem ainda 


\section{VOZES $_{\text {\&IÁLORO }}^{\mid}$}

Itajaí, V. 20, n.01, jan-jun 2021

armários ao fundo, bancos por toda a parte e duas grandes janelas que permitem a entrada de luz no ambiente. As paredes com tijolos à vista deixam o cenário com aspecto robusto e o chão representa uma extensão do gramado.

Mais adiante, no fim do comercial — demonstrado pelo último keyframe da Figura 4 -, identificam-se algumas das estrelas da Seleção Feminina, todas estão com uniformes da Seleção Brasileira, camisa verde e amarela, cabelos presos e visivelmente cansadas pelo esforço físico deixado dentro de campo. Percebe-se, de imediato, que se trata de um ato de comemoração entre as profissionais e, apesar do plano não evidenciar grandes detalhes, identificamos expressões, gestos de total entrega e paixão pela profissão escolhida. Vale destacar a jogadora que está no centro da imagem, manifestando tamanha intensidade na comemoração. Assim, a narrativa termina com uma sequência de planos abertos das atletas da Seleção, em que seus rostos, olhos e fala são evidenciados.

Observando a narrativa proposta pelo comercial, é importante ressaltar a trilha sonora da peça, que ajuda a alavancar conexões emocionais com o espectador, criando, através dos planos de imagem, uma relação próxima e afetiva. Outro ponto alto da narrativa trata-se do cenário externo em que se encontra, época de Copa do Mundo. O comercial publicitário selecionado foi veiculado a menos de dois meses para o início da Copa do Mundo Feminina da FIFA, na França. A peça publicitária destaca as jogadoras que participaram do mundial na França, mostrando o trabalho, a luta e as glórias das atletas pela voz da melhor do mundo, Marta. "Não se espante com meu drible, com meu passe, com meu chute. Não se espante com meu abraço. Com o que eu faço com a bola. Cada gota de suor que eu deixo em um gramado não é a razão. É consequência.” diz a camisa 10 da Seleção Brasileira, eleita seis vezes a melhor do mundo.

Assim, se para Barthes (2001) o mito é uma fala, compreende-se, neste sentido, que os diversos meios de comunicação podem servir de apoio para a construção dos mitos modernos. Logo, se a formação de um mito se dá na relação da fala, podemos entender este comercial publicitário como uma narrativa mítica. Nesta lógica, a visão de Lisboa (2018) e Rowe (2018) complementa e traz o mito como um modelo real para a sociedade e não mais apenas em fantasias, logo, o mito passa a ser uma verdade que contribui dentro da realidade do nosso cotidiano, por meio de palavras, gestos, imagens, no esporte e na publicidade.

Além disso, no contexto narrativo em questão, o comercial convida para olhar o futebol feminino por diversos sentidos. Sendo assim, ressalta-se que o envolvimento com o espectador é de extrema importância para que a mensagem seja entregue, isto é, quanto maior for a proximidade da peça publicitária com o espectador, mais fácil se entenderá o universo das jogadoras apresentado.

Sendo assim, considera-se que, como dito anteriormente, a publicidade pode ser compreendida não somente como uma possível estratégia de venda ou serviço, mas também como algo a ser consumido através de histórias curtas, como o comercial 


\section{VOZES $_{\text {\&IÁLORO }}$}

Itajaí, V. 20, n.01, jan-jun 2021

selecionado, porém densas, criando empatia, diálogo e afeto com o espectador (ZHENG; PHELPS; PIMENTEL, 2019). Dessa forma, o comercial apresenta, junto à narrativa, a impressionante história das atletas, em flashes de jogos, disputas de títulos, de inúmeras vitórias, abraços, gritos de dor e comemorações, porém com muito suor, sacrifícios e um árduo caminho, que marcam a trajetória de cada estrela que representa o futebol feminino no Brasil.

Deste modo, pode-se dizer que o comercial publicitário selecionado envolve características míticas incorporadas junto à narrativa, uma vez que, através da narrativa, são expostos comportamentos míticos, revelando histórias verdadeiras e, assim, cria-se um elo forte com o espectador durante a edição da Copa do Mundo. O futebol não é feito apenas de histórias cheias de glamour e fama, é, acima de tudo, composto por superação, desafios, luta para transformar sonhos de infância em profissão e fatos que nos mostram que nunca será, apenas, só futebol.

Quadro 4-Quadro-Síntese

\begin{tabular}{|c|c|}
\hline \multicolumn{2}{|c|}{ Comercial Sportv } \\
\hline Viés denotado & Viés conotado \\
\hline $\begin{array}{l}\text { Marta, driblando a adversária em uma partida } \\
\text { de futebol. }\end{array}$ & $\begin{array}{l}\text { Remete-se a um alto grau técnico de } \\
\text { habilidade da jogadora que traz para dentro } \\
\text { de campo todo o seu esforço e trabalho nos } \\
\text { treinos. }\end{array}$ \\
\hline $\begin{array}{l}\text { Marta abraça outras duas jogadoras da } \\
\text { Seleção durante uma partida oficial. }\end{array}$ & $\begin{array}{l}\text { Relação de afeto entre as jogadoras em busca } \\
\text { de um objetivo coletivo. O compartilhar de um } \\
\text { mesmo sonho, uma mesma alegria. }\end{array}$ \\
\hline $\begin{array}{l}\text { Debinha está deitada em um campo de } \\
\text { futebol em treinamento. É possível visualizar } \\
\text { gotas de suor em seu rosto. }\end{array}$ & $\begin{array}{l}\text { Remete ao estado físico da atleta que se } \\
\text { encontra totalmente exausta após o treino. } \\
\text { Nota-se o cansaço, o suor do esforço e } \\
\text { dedicação para com a profissão escolhida. }\end{array}$ \\
\hline $\begin{array}{l}\text { Em uma academia de treinamento com } \\
\text { diversos aparelhos e equipamentos, Tamires } \\
\text { está realizando exercícios físicos. }\end{array}$ & $\begin{array}{l}\text { Dedicação, esforço e foco nos objetivos. Trata- } \\
\text { se do trabalho duro da atleta que demonstra } \\
\text { toda a garra, seriedade e entrega nos } \\
\text { exercícios. }\end{array}$ \\
\hline $\begin{array}{l}\text { Atletas da Seleção Brasileira estão abraçadas } \\
\text { vestindo o uniforme verde e amarelo em um } \\
\text { campo de futebol durante uma partida oficial. }\end{array}$ & $\begin{array}{l}\text { Em um ato de comemoração, de glória, as } \\
\text { atletas se abraçam, reforçando o trabalho } \\
\text { coletivo em busca de conquistas e vitórias. }\end{array}$ \\
\hline
\end{tabular}

Fonte: Elaborado pelos autores

Posto isto, o presente estudo encaminha-se ao seu final apresentando, na sequência, as considerações finais delineadas., 


\section{VOZES $_{\text {\&IÁLORO }}^{\mid}$}

Itajaí, V. 20, n.01, jan-jun 2021

\section{Considerações finais}

Na história do futebol, nenhuma Copa do Mundo Feminina teve tanta audiência, já que, justamente, os números obtidos na edição de 2019 representaram um recorde histórico no torneio, atraindo 1,12 bilhão ${ }^{18}$ de espectadores. É notório e importante ressaltar, ainda, o grande destaque que o futebol feminino adquiriu na sociedade contemporânea e, isso, graças à influência dos meios de comunicação, garantindo o acesso a informações no meio esportivo. Em 2019, de certa forma, a mídia contribuiu, ainda mais, para consolidar a visão dos espectadores e das empresas sobre a modalidade. Nesse sentido, a mídia, que está presente em vários aspectos de nossas vidas, influenciou de forma significativa a visibilidade do futebol feminino e influencia, até hoje, a construção publicitária e mítica de jogadoras.

Nesse sentido, na publicidade, utilizando diferentes ferramentas do audiovisual, os comerciais selecionados emocionaram os espectadores com a história de atletas brasileiras que, no decorrer desta pesquisa, expuseram sua trajetória de vida e de carreira. Já no aspecto mítico, viu-se um padrão de narrativas semelhantes: o poder de superação das atletas ressaltando a persistência e a determinação, além da capacidade de acreditar em si frente aos obstáculos de vida e de carreira, que não as fizeram desistir de seus objetivos estabelecidos já desde a infância - como foi, explicitamente, demonstrado nas narrativas das jogadoras Marta e Andressa.

Ainda, o que desperta a atenção nos comerciais publicitários estudados é a repetição de alguns pontos, tais como: o talento, a superação e a habilidade com a bola e, até mesmo, a própria “alegria” das jogadoras reproduzida nas peças, o que remete à brasilidade que o espectador tanto admira, características marcantes e, também, fundamentais para se alcançar o sucesso no esporte. $\mathrm{O}$ atleta-mito personifica, portanto, a figura com a qual muitas pessoas se identificam, sendo considerado um modelo exemplar para a humanidade, com seus desafios, dificuldades e sofrimentos, com as suas vitórias e derrotas; enfim, com a luta pela sua história.

Dessa forma, podemos considerar, também, a vitória como um componente importante na construção da história das atletas brasileiras, tornando, assim, seus cenários míticos. Observa-se, então, que as narrativas inseridas no contexto da Copa do Mundo conduziram os espectadores à identificação com atletas já consolidadas no futebol por, justamente, suas trajetórias consagradas. Sendo assim, este trabalho, que visava analisar a construção mítica e publicitária das atletas da Seleção Brasileira em peças veiculadas durante a Copa do Mundo de Futebol Feminino 2019 teve seu objetivo atingido, trazendo, portanto, como contribuição o entendimento de que é possível identificar, através de peças

\footnotetext{
${ }^{18}$ Disponível em: <https://img.fifa.com/image/upload/rvgxekduqpeolptbgeng.pdf>. Acesso em: 19 mar. 2020.
} 


\section{VOZES $_{\text {\&IÁLORO }}^{\mid}$}

Itajaí, V. 20, n.01, jan-jun 2027

publicitárias, que determinadas narrativas em comerciais contribuem para a construção de mitos esportivos.

Por fim, explorando sua continuidade, apresenta-se como sugestão de estudos futuros a aplicação da técnica de análise elencada neste artigo em outras peças publicitárias relacionadas à Copa do Mundo de Futebol Feminino 2019 ou, até mesmo, de anos anteriores. Ainda, como sugestão, pode-se realizar a análise de peças publicitárias veiculadas durante outros megaeventos esportivos, a fim de estabelecer comparações e confrontações com as análises aqui realizadas.

\section{Referências}

BARTH, M.; SANFELICE, G. R. When Scientific Production Enters in Field: Bibliometrics Appointments about Soccer. International Journal of Advanced Engineering Research and Science, v. 6, issue 3, march 2019.

BARTHES, R. O Óbvio e o obtuso: ensaios críticos III. Rio de Janeiro: Nova Fronteira, 2001.

O óbvio e o obtuso: ensaios sobre fotografia, cinema, teatro e música. RJ:

Nova Fronteira, 1990.

et al. Análise estrutural da narrativa. 7. ed. Petrópolis, RJ: Vozes, 2011.

BAUDRILLARD, J. O sistema dos objetos. 4. ed. São Paulo, SP: Perspectiva, 2000 .

BHARADWAJ, N. et al. Cross-Media Consumption: Insights from Super Bowl Advertising. Journal of Interactive Marketing, v. 50, 2020, p. 17-31.

CAMARGO, H. W. de. Mito e filme publicitário: estruturas de significação. São Paulo: SciELO-EDUEL, 2016.

CAMPBELL, J.; MOYERS, B. O poder do mito. 30. ed. São Paulo, SP: Palas Athena, 2014.

ELIADE, M. Mito e realidade. São Paulo, SP: Perspectiva, 1972.

GIL, A. C. Métodos e técnicas de pesquisa social. 6. ed. 5. reimpr. São Paulo: Atlas, 2012.

LAKATOS, E. M.; MARCONI, M. de A. Metodologia científica. 7. ed. São Paulo: Atlas, 2017. 


\section{VOZES $_{\& \text { DIÁLORO }}^{\mid}$}

Itajaí, V. 20, n.01, jan-jun 2027

LISBOA, A. Há verdade nos mitos? Um convite aos estudos mitológicos. São Paulo: Escola de Filosofia, 2018.

LLOYD, H. R. The Myth of Giving as Good: Charitable Giving Represented as an End in itself. Discourse, Context and Media, v. 25, 2018, p. 122-131.

PRODANOV, C. C.; FREITAS, E. C. de. Metodologia do trabalho científico: métodos e técnicas da pesquisa e do trabalho acadêmico. 2. ed. Novo Hamburgo, RS: Feevale, 2013.

ROWE, D. Money, Myth and the Big Match: The Political Economy of the Sports Media. In: WASHINGTON, Robert E. (Org). Sport, Power, and Society: Institutions and Practices. New York: Taylor \& Francis, 2018.

RUBIO, K. O atleta e o mito do herói: o imaginário esportivo contemporâneo. São Paulo: Casa do Psicólogo, 2001.

SILVA, K.; COVALESKI, R. Narrativas Publicitárias: a Diferença como Estratégia Discursiva na Contemporaneidade. Comunicom, São Paulo, 2016

SILVERSTONE, R. Por que estudar a mídia? 4. ed. São Paulo, SP: Loyola, 2014.

TUASTAD, S. The Scandinavian Sport Model: Myths and Realities. Norwegian Football as a Case Study. Soccer and Society, v. 20, n. 2, 2019, p. 341-359.

YIN, R. K. Estudo de caso: planejamento e métodos. 5. ed. Porto Alegre: Brookman, 2015.

ZHENG, L.; PHELPS, J.; PIMENTEL, D. Psychological Transportation in Narrative Advertising. 2. ed. Florida: Advertising Theory, 2019. 